\title{
The Results of the Modern Demographic Policy in Russia
}

\author{
Larisa A. Popova (Corresponding Author) \\ Institute of Socio-Economic and Energy Problems of the North Komi Scientific Centre, \\ Ural Branch of the Russian Academy of Sciences \\ 26 Kommunisticheskaya Street, Syktyvkar 167982, Russia \\ E-mail: popova@iespn.komisc.ru
}

Received: September 12, 2014 Accepted: October 6, 2014 Published: October 14, 2014

doi:10.5296/ijrd.v1i1.6438 URL: http://dx.doi.org/10.5296/ijrd.v1i1.6438

\begin{abstract}
The article reveals how the demographic processes in Russia are influenced by federal and regional demographic policy measures of 2006-2011 and by the national project "Health" and health care modernization programmes for 2011-2012. The author dwells upon the modem trends in the birth rate of Russia's population, upon the changes in its structure by the age and marital status of mother. The article evaluates which actual generations have received the maximum reproductive benefit from pronatalist demographic policies, and what are the prospects concerning fertility. The article considers the dynamics of life expectancy of Russia's population and the changes in the structure of mortality by causes.
\end{abstract}

Keywords: Russia, Demographic policy, National projects, Health of the population, Fertility, Mortality, Life expectancy

\section{Level and Structure of Russian Birth Rate in the 2000s}

In 2010-2011 the influence of the structural factor in enhancing the level of fertility in Russia came to an end: the number of women of the main childbearing age (up to 35 years) began to reduce because the small generations of the 1990s reached their fertile age. In these conditions birth rate can be maintained at a relatively high level only by enhancing its intensity. Therefore, issues related to the possibility of influencing birth rate intensity, the assessment of the effects of the state demographic policy of recent years and expected birth rate prospects, are of considerable interest.

As is known, birth rate indicators in Russia conditions began to increase in 2000, after a 12-year period of fertility decline, during which the annual number of births in the country decreased more than twice (from 2500 thousand in 1987 to 1215 thousand in 1999). 1896.3 
thousand children were born in 2012 [15], that is by $56.1 \%$ more than it was in 1999. Birth rate was increasing while the number of population was decreasing, therefore, the value of the overall coefficient increased more significantly during this time: by $60.2 \%$ (from 8.3 births per 1.000 population in 1999 up to 13.3 births in 2012).

The birth rate increase occurred largely due to the structural factor: until the end of the last decade Russia witnessed the improvement in the age structure of reproductive contingents, since the relatively numerous generations born in the early- and mid-1980s were reaching the active childbearing age. However, the birth rate intensity has also increased quite noticeably, as evidenced by the dynamics of the total fertility rate (table. 1), which increased from 1.16 children in 1999 up to 1.58 children in 2011 (by 36.2\%).

Table 1. Age-specific fertility rates in the Russian Federation in 2000-2011

\begin{tabular}{|l|l|l|l|l|l|l|l|l|l|}
\hline \multirow{2}{*}{ Year } & \multicolumn{2}{|c|}{ Average annual number of births per 1000 women aged, years } & \multicolumn{2}{|}{$\begin{array}{l}\text { Total } \\
\text { fertility } \\
\text { rate }\end{array}$} \\
\cline { 2 - 11 } & $15-19$ & $20-24$ & $25-29$ & $30-34$ & $35-39$ & $40-44$ & $45-49$ & $15-49$ \\
\hline 2000 & 27.4 & 93.6 & 67.3 & 35.2 & 11.8 & 2.4 & 0.1 & 32.1 & 1.195 \\
\hline 2001 & 27.3 & 93.1 & 70.2 & 38.0 & 12.9 & 2.4 & 0.1 & 33.1 & 1.223 \\
\hline 2002 & 27.4 & 95.7 & 75.1 & 41.7 & 14.7 & 2.6 & 0.1 & 35.2 & 1.286 \\
\hline 2003 & 27.6 & 95.3 & 78.3 & 44.0 & 16.0 & 2.7 & 0.1 & 36.5 & 1.320 \\
\hline 2004 & 28.2 & 94.2 & 80.1 & 45.8 & 17.6 & 2.9 & 0.1 & 37.7 & 1.344 \\
\hline 2005 & 27.4 & 88.4 & 77.8 & 45.3 & 17.8 & 3.0 & 0.2 & 36.9 & 1.294 \\
\hline 2006 & 28.2 & 87.8 & 78.4 & 46.6 & 18.6 & 3.1 & 0.1 & 37.7 & 1.305 \\
\hline 2007 & 28.3 & 89.5 & 86.9 & 54.1 & 22.7 & 3.9 & 0.2 & 41.4 & 1.416 \\
\hline 2008 & 29.3 & 91.2 & 92.4 & 60.0 & 25.8 & 4.6 & 0.2 & 44.6 & 1.502 \\
\hline 2009 & 28.7 & 90.5 & 95.9 & 63.6 & 27.6 & 5.2 & 0.2 & 46.4 & 1.542 \\
\hline 2011 & 26.7 & 87.5 & 99.8 & 68.2 & 31.4 & 6.3 & 0.3 & 48.8 & 1.582 \\
\hline
\end{tabular}

In the first years, in the conditions of economic stabilization, the birth rate increase was determined by the increase in the number of newborns, whose birth had been "postponed" by 
their parents due to the then unfavorable economic situation. The growth is reflected in the dynamics of age-specific fertility rates. The increase in the indicators was observed solely in the age groups of 25 to 44 years (tab. 1 and 2) in 2000. And further, up to 2004, these very ages made the main contribution to the enhancement of the overall fertility level.

Table 2. Rates of increase in fertility indicators in the Russian Federation in 2000-2011, \%

\begin{tabular}{|c|c|c|c|c|c|c|c|c|c|}
\hline \multirow{2}{*}{ Year } & \multicolumn{8}{|c|}{ Average annual number of births per 1000 women aged, years } & \multirow{2}{*}{$\begin{array}{l}\text { Total } \\
\text { fertility } \\
\text { rate }\end{array}$} \\
\hline & $15-19$ & $20-24$ & $25-29$ & $30-34$ & $35-39$ & $40-44$ & $45-49$ & $15-49$ & \\
\hline $2000-2001$ & -0.4 & -0.5 & 4.3 & 8.0 & 9.3 & 0.0 & 0.0 & 3.1 & 2.3 \\
\hline 2001-2002 & 0.4 & 2.8 & 7.0 & 9.7 & 14.0 & 8.3 & 0.0 & 6.3 & 5.2 \\
\hline $2002-2003$ & 0.7 & -0.4 & 4.3 & 5.5 & 8.8 & 3.8 & 0.0 & 3.7 & 2.6 \\
\hline $2003-2004$ & 2.2 & -1.2 & 2.3 & 4.1 & 10.0 & 7.4 & 0.0 & 3.3 & 1.8 \\
\hline $2004-2005$ & -2.8 & -6.2 & -2.9 & -1.1 & 1.1 & 3.4 & 100.0 & -2.1 & -3.7 \\
\hline $2005-2006$ & 2.9 & -0.7 & 0.8 & 2.9 & 4.5 & 3.3 & -50.0 & 2.2 & 0.9 \\
\hline $2006-2007$ & 0.4 & 1.9 & 10.8 & 16.1 & 22.0 & 25.8 & 100.0 & 9.8 & 8.5 \\
\hline $2007-2008$ & 3.5 & 1.9 & 6.3 & 10.9 & 13.7 & 17.9 & 0.0 & 7.7 & 6.1 \\
\hline 2008-2009 & -2.0 & -0.8 & 3.8 & 6.0 & 7.0 & 13.0 & 0.0 & 4.0 & 2.7 \\
\hline $2009-2010$ & -5.9 & -3.3 & 3.4 & 5.8 & 8.7 & 13.5 & 50.0 & 3.0 & 1.6 \\
\hline $2010-2011$ & -1.1 & 0.0 & 0.6 & 1.3 & 4.7 & 6.8 & 0.0 & 2.1 & 1.0 \\
\hline $\begin{array}{l}\text { Total for } \\
2000-2011\end{array}$ & -2.6 & -6.5 & 48.3 & 93.8 & 166.1 & 162.5 & 200.0 & 52.0 & 32.4 \\
\hline
\end{tabular}

Unfortunately, this conclusion cannot be supported using the dynamics of fertility structure by birth order, because, according to the Federal Law No. 143-FL "On civil status acts" dated November 15. 1997, since 1999 the information about birth order has been excluded from birth registration records. It the first half of the 2000s, the share of births with unstated birth order was very significant even in those RF subjects, where such statistics were maintained on the basis of medical birth certificates (about 60 regions out of 80 ).

For example, in the Komi Republic in 1999 birth order was not specified in $4.3 \%$ of cases, and 
in 2000 this figure reached $52.4 \%$. In 2001, the statistics did not include birth order in $17.6 \%$ of cases, in 2002 - in $16.5 \%$ of cases, in 2004 - in $6.6 \%$ of cases.

In 2005, Russia experienced a decrease in fertility. Although, we should emphasize that the structural factor at that time played an important part in the increase of its level. Obviously, the stage of spontaneous realization of "postponed" births, which required no incentive measures, almost came to an end by this time. In the stated year the improvement in the performance of indicators was observed only in the oldest groups of reproductive age: apparently, the planned births of high order were realized among the representatives of generations born in 1956-1970, who in the beginning of the decade realized the previous "postponed" births.

\section{Measures of State Demographic Policy in Fertility}

In these circumstances, we should consider it very timely that the 2006 Presidential Address to the Federal Assembly singled out demographic issues as the key and most acute problems of modern Russia. The legislative and executive authorities were given the task to launch the active demographic policy aimed at birth rate stimulation, and its implementation was to begin no later than January 1. 2007. The execution of the "Consolidated plan of actions on the implementation of the main provisions of the 2006 Address of the President of the Russian Federation to the Federal Assembly of the Russian Federation" resulted in the adoption of several Federal Laws in November - December 2006 ("On the introduction of amendments to certain legislative acts of the Russian Federation on the provision of state support to the citizens with children". dated December 5. 2006 No. 207-FL. "On the provision of temporary disability allowances, maternity allowances to the citizens subject to compulsory social insurance" dated December 29.2006 No. 255- FL. "On additional measures of state support to families with children", dated December 29.2006 No. 256-FL; according to this law. the state certificate on maternity (family) capital was introduced on January 1.2007); and in the elaboration of the "Concept for demographic policy of the Russian Federation for the period up to 2025” approved by the Presidential Decree dated October 9, 2007 No. 1351.

At that, it is necessary to highlight the differentiated approach to promoting births of different order, which was proclaimed after a long break. The second child, who is often very wanted, was considered a priority (according to the VTSIOM (All-Russian Center for the Study of Public Opinion) annual representative surveys. even in the 1990s. except for 1992 and 1994. the average desired number of children and the average ideal number of children in the family were higher than two), but there are too many impeding factors for the birth of the second child in families that consciously plan their life.

\subsection{Positive Results of Federal Demographic Initiatives in Fertility}

The Address to the Federal Assembly played a certain, purely psychological, role even before the launch of the new demographic policy, because the Address set out the official government policy that consistently continued a new social policy of the state, the policy expressed in the national priority projects that had been launched in the beginning of the year. Most age groups (except for those aged 20-24 and 45-49) experienced some increase in 
fertility intensity in 2006 already, which determined the growth of the total fertility rate in that year in general.

In 2007-2008, when the increase in the total fertility rate was maximum (by $8.5 \%$ and $6.1 \%$, respectively), the increase in the intensity of fertility was observed in all age groups, with the increase of growth rates among the people of older age. As a result, the increase in birth rate in 2008 shifted from the group of people aged 20-24 to those aged 25-29. However, the most significant increase was observed among people aged over 35 . It is obvious that it was the period when the "postponed" children were born; it required a certain impetus, which means that they would not have happened without the appropriate demographic policy.

If we turn our attention from the age-specific coefficients for relative generations to actual cohorts of women, for which these coefficients are characteristic in a given year of observation, we can observe what generations have received the maximum "reproductive benefit" from the new demographic initiatives of the government (table. 3). Most of all they contributed to the realization of final fecundity of generations born 1963-1973: in 2007-2008 age-specific birth intensity of these generations increased by $14-26 \%$. The generations born in 1973-1983 also got a significant impetus to the fulfillment of their reproductive plans they experienced the 6-16\% increase in birth rate intensity. In addition, the measures to boost fertility in the first two years after their adoption partly stimulated the cohorts born in 1983-1993 to implement their fertility earlier.

Table 3. Actual generations that facilitated the growth of the total fertility rate in 2007-2011, by years of birth (growth rate, \%)

\begin{tabular}{|c|c|c|c|c|c|c|}
\hline \multirow{2}{*}{ Year } & \multicolumn{6}{|c|}{ Age groups, years } \\
\hline & $15-19$ & $20-24$ & $25-29$ & $30-34$ & $35-39$ & $40-44$ \\
\hline 2007 & $\begin{array}{l}1988-1992 \\
(0.4 \%)\end{array}$ & $\begin{array}{l}1983-1987 \\
(1.9 \%)\end{array}$ & $\begin{array}{l}1978-1982 \\
(10.8 \%)\end{array}$ & $\begin{array}{l}1973-1977 \\
(16.1 \%)\end{array}$ & $\begin{array}{l}1968-1972 \\
(22.0 \%)\end{array}$ & $\begin{array}{l}1963-1967 \\
(25.8 \%)\end{array}$ \\
\hline 2008 & $\begin{array}{l}1989-1993 \\
(3.5 \%)\end{array}$ & $\begin{array}{l}1984-1988 \\
(1.9 \%)\end{array}$ & $\begin{array}{l}1979-1983 \\
(6.3 \%)\end{array}$ & $\begin{array}{l}1974-1978 \\
(10.9 \%)\end{array}$ & $\begin{array}{l}1969-1973 \\
(13.7 \%)\end{array}$ & $\begin{array}{l}1964-1968 \\
(17.9 \%)\end{array}$ \\
\hline 2009 & & & $\begin{array}{l}1980-1984 \\
(3.8 \%)\end{array}$ & $\begin{array}{l}1975-1979 \\
(6.0 \%)\end{array}$ & $\begin{array}{l}1970-1974 \\
(7.0 \%)\end{array}$ & $\begin{array}{l}1965-1969 \\
(13.0 \%)\end{array}$ \\
\hline 2010 & & & $\begin{array}{l}1981-1985 \\
(3.4 \%)\end{array}$ & $\begin{array}{l}1976-1980 \\
(5.8 \%)\end{array}$ & $\begin{array}{l}1971-1975 \\
(8.7 \%)\end{array}$ & $\begin{array}{l}1966-1970 \\
(13.5 \%)\end{array}$ \\
\hline 2011 & & & $\begin{array}{l}1982-1986 \\
(0.6 \%)\end{array}$ & $\begin{array}{l}1977-1981 \\
(1.3 \%)\end{array}$ & $\begin{array}{l}1972-1976 \\
(4.7 \%)\end{array}$ & $\begin{array}{l}1967-1971 \\
(6.8 \%)\end{array}$ \\
\hline
\end{tabular}


Already in 2009-2011, fertility growth rates decreased significantly. And the groups aged up to 24 once again witnessed a reduction in age-specific rates. It is necessary to note that the 2000 s, in general, are characterized by the decrease in the intensity of fertility in the two youngest age groups. At the same time, the group aged 30-34 almost doubled the age-specific birth rate in 2000-2011; the groups aged 35-39 and 40-44 increased their birth rate by 2.6 times. In other words, the past decade witnessed a major shift in the age-specific fertility model of the Russian population. This shift, in our opinion, is very positive, it indicates the strengthening of the consciousness related to fertility.

The maximum increase in birth rate intensity in 2009-2011 is characteristic of actual generations born in 1966-1980. The generations born in 1981-1986 also contributed to the increase in the total fertility rate in these years. Consequently, the demographic initiatives of 2006-2007 played a positive and stimulating role for all the older generations of women born before the mid-1980s inclusive. At the same time, the generations born in 1987-1996 have not experienced any significant stimulating effects of demographic policy on the intensity of fertility.

The governmental demographic initiatives of 2006-2007 helped the older generations to realize their reproductive plans, which had been postponed year upon year; the initiatives also contributed to the increase in the population's reproductive expectations. According to the sampling survey "Family and fertility" [5] conducted by Rosstat (Federal State Statistics Service) in September - October 2009, in 30 constituent entities of the Russian Federation, the average expected number of children for women is 1.72 , for men -1.90 , the average desired number of children for women is 2.28 , for men -2.38 , which is considerably higher than the reproductive expectations of the Russians identified in the VTSIOM surveys in 1991-2000.

The share of children born in wedlock has also increased; no doubt, it is a positive result of the 2006-2007 demographic policy. After two odd decades of growth, the level of illegitimate birth rate in Russia declined from 30\% in 2005 to $24.6 \%$ in 2011 [13].

\subsection{Negative Consequences of Family Population Policy in 2006-2007}

On the other hand, the 2006-2007 demographic policy led to the compression of birth timing and an early realization of reproductive plans of the generations that at the time, when the new measures were being introduced, were in the most active fertile age. And at present these generations are, in fact, the most numerous generations that were born in the early- and mid-1980s.

Accordingly, the forthcoming structural reduction in the level of fertility that will last for at least two decades will be reinforced by the reduction of the intensity of fertility as a result of the reverse timing processes.

In addition, according to the results of our 2008-2009 survey, the demographic policy exerted a maximum positive effect on the level of reproductive expectations among the cohorts born in the second half of the 1980s. The policy had virtually no impact on the reproductive attitudes of the generations born in the 1990s: their expected child birth rate is the same as of those born in the late 1970s-early 1980s. It means that the forthcoming structural reduction in 
the level of fertility can turn out to be increased by the anticipated early depletion of the final fertility rate of the generations born in the 1980s, and also by the reduced reproductive activity of the generations born in the 1990s.

\section{Results of Motivation Measures for the Third Births}

Under these circumstances, undoubtedly, it is necessary to boost the demographic policy. The first step was made in the 2010 Presidential Address to the Federal Assembly. in which the President suggested that the Government together with the regions work out the procedure of the one-time provision of a land plot on a free-of-charge basis for the purpose of building a dwelling house or a dacha house to the families at the birth of the third (or subsequent) child. In accordance with this, in 2011 some of Russia's constituent entities elaborated certain regional laws on the provision of land plots to large families free of charge.

Many regions in 2011 adopted laws on the regional maternity capital for the third and subsequent child. For example, in the Republic of Komi, the Republican Law "On additional measures of providing social support to families with children, on the territory of the Republic of Komi" dated April 29.2011 No. 45 entered into force on July 1. 2011. The amount of the regional family capital is 150 thousand rubles, it can be disposed of after the expiration of six months from the day of birth of the third child or subsequent children born in the period frost January 1. 2011 to December 31. 2016. The money can be used for improving the housing conditions, for covering the expenses on education of the child (children), for providing the child (children) with paid medical services. In addition, this law provides for an annual lump-sum payment at the expense of the regional family capital in the amount of 25 thousand rubles, which can be used to pay the family's housing and utilities bills, taxes; to pay for the children's preschool education, family property insurance, child's (children's) life insurance. In 2011 , the total fertility rate in the Komi Republic amounted to $13.1 \%$ against $12.9 \%$ in 2010. At that, 1363 children of the third order were born, which is $7.5 \%$ more than in 2010 . The share of high-order births in 2011 amounted to $11.7 \%$ in comparison with $10.9 \%$ in 2010 .

However, the measures aimed to promote the birth of the third child, were, in fact, addressed to the same generations that previously responded to the promotion of the second birth. This means they also contribute to the compression of birth timing and a more complete exhaustion of the final childbearing in relation to numerous cohorts born in the 1980s. Accordingly, in the coming years, these generations will contribute virtually nothing to birth rate, and it will be determined mostly by the reproductive behavior of small cohorts born in the 1990s. In other words, what we currently need is not just another demographic policy impetus. The policy should be focused I on these very generations, since neither the federal initiatives in demographic sphere in 2006-2007, nor the regional laws of 2011 have had any noticeable positive influence on the models of their reproductive behavior.

\section{Modern Russian Socio-Demographic Policy in Mortality}

The success of the 2000s in the field of reducing mortality is also very impressive. Since 2004 Russia has witnessed a downward trend in the level of mortality. The decline has not been completely consistent: there was some increase in the total mortality in 2005 and 2010; but in 
general in the 2003-2012 period its value decreased from 16.4 deaths per 1.000 population to $13.3 \%$ (18.9\%). Life expectancy of the Russian population increased from 64.8 years in 2003 to 69.8 in 2011 (in men-from 58.5 to 64 years. in women-from 71.9 to 75.6 years) (table 4 ).

Table 4. Life expectancy at birth among the population of the Russian Federation, years

\begin{tabular}{|l|l|l|l|l|l|l|l|}
\hline Year & Both sexes & Men & Women & Year & Both sexes & Men & Women \\
\hline 1959 & 67.9 & 63.0 & 71.5 & 1999 & 65.9 & 59.9 & 72.4 \\
\hline 1970 & 68.9 & 63.2 & 73.6 & 2000 & 65.0 & 58.9 & 72.4 \\
\hline 1979 & 67.6 & 61.5 & 73.1 & 2001 & 65.2 & 58.9 & 72.2 \\
\hline 1987 & 70.1 & 64.9 & 74.6 & 2002 & 65.0 & 58.7 & 71.9 \\
\hline 1989 & 69.6 & 64.2 & 74.5 & 2003 & 64.8 & 58.5 & 71.9 \\
\hline 1990 & 69.2 & 63.7 & 74.3 & 2004 & 65.3 & 58.9 & 72.3 \\
\hline 1991 & 69.0 & 63.5 & 74.3 & 2005 & 65.3 & 58.9 & 72.4 \\
\hline 1992 & 67.9 & 62.0 & 73.8 & 2006 & 66.7 & 60.4 & 73.3 \\
\hline 1993 & 65.1 & 58.9 & 71.9 & 2007 & 67.6 & 61.5 & 74.0 \\
\hline 1994 & 64.0 & 57.6 & 71.2 & 2008 & 68.0 & 61.9 & 74.3 \\
\hline 1995 & 64.6 & 58.2 & 71.7 & 2009 & 68.8 & 62.9 & 74.8 \\
\hline 1996 & 65.8 & 59.6 & 72.4 & 2010 & 68.9 & 63.1 & 74.9 \\
\hline 1997 & 66.6 & 60.8 & 72.9 & 2011 & 69.8 & 64.0 & 75.6 \\
\hline 1998 & 67.0 & 61.3 & 72.9 & & & & \\
\hline
\end{tabular}

As is known, since 2006 the Russian Federation has been implementing health care reforms. On January 1, 2006 the national project "Health" was launched. It provides for the activities aimed at the development of primary health care, enhancement of disease prevention, improvement of the availability and quality of specialized, including high-tech, medical care, improvement of medical care provided to mothers and children, promotion of the population's healthy lifestyle.

Taking into account the specifics of mortality in Russia, it is, of course, necessary to point out 
the federal target program "Enhancement of traffic safety in 2006-2012" (in the framework of the RF Government Resolution of the dated February 20, 2006 No. 100) and "Prevention and treatment of socially significant diseases (2007-2012)" (in the framework of the RF Government Resolution dated May 10, 2007 No. 280).

The "Concept for demographic policy of the Russian Federation for the period up to 2025" approved in October 2007 sets out definite quantitative targets with regard to Russia's population and its life expectancy: stabilization of the number of population by 2015 at the level of 142-143 million people and establishment of conditions for its growth up to 145 million people by 2025, as well as the enhancement of the quality of life and increase in life expectancy up to 70 years by 2015, and up to 75 years by 2025 .

It is completely reasonable that the tasks concerning mortality occupy the first place in the list of the main tasks of Russia's demographic policy. Emphasis is placed on the following activities: reduction of mortality rate from external causes primarily among the working-age population; reduction of maternal and infant mortality; enhancement of reproductive health of the population, the health of children and adolescents; preservation and enhancement of the population's health; increase in active life expectancy; creation of conditions and formation of motivation to lead a healthy life: substantial decrease in the incidence of socially significant diseases and diseases that constitute a danger to others; improvement of the quality of life of patients with chronic illnesses or disabilities.

The measures in the framework of the priority national project "Health" were continued in the regional programs for modernization of health care for 2011-2012; the programs were funded mainly through the subsidies allocated by the Federal Compulsory Medical Insurance Fund (and also by regional budgets and regional health insurance funds). Each region works out these programs on its own in accordance with the guidelines that are determined by the Ministry of Health and that will receive federal funding: improvement of facilities and infrastructure, introduction of modern information systems and uniform standards of medical care.

The first guideline is aimed at aligning the regional health care systems and creating conditions for the introduction of standards. The purpose of informatization is to improve the quality and availability of medical services and the transparency of funding. The third component (introduction of standards) consists in defining the set of medical services that should be provided for treating a certain illness. The cost of the standard (it is assumed there will be 1190 standards all in all) includes everything: medicines, consumables, salaries of medical staff, patients' nutrition. When developing the programs, regional authorities themselves determined which medical institutions were in a greater need of funding, and which are ready for the introduction of the standards, etc. The programs were approved in 2011 in each Russian region and were to have been implemented before the end of 2012; however, they have been extended for the current year.

\section{Results Policies Mortality}

So, what are the results of these activities? First, it is necessary to point out the duration of 
the period of decline in mortality observed in Russia for nine years already, i.e. it is quite stable (we have already noted small deviations of 2005 and 2010). In other words, now it cannot be assessed as a short reduction of compensatory type occurring after several years of super mortality, leading to the "improvement of the population's health"; in this way it is possible to estimate, for example, the reduction in mortality among Russia's population in the 1995-1998 period.

Secondly, we should point out the achieved level of life expectancy. As is known, the maximum life expectancy of Russia's population was recorded in the mid-1960s and late 1980s. In the mid-1960s life expectancy in men reached 64.6 years (in 1964-1965) and 73.54 years in women (in 1967-1968); after that the stagnation and decline in its value have been observed for almost two decades. As for the life expectancy indicators of 1986-1987 that were 70.13 years for the entire population 64.91 years in men and 74.55 years in women, are the highest for the entire history of Russia. In 2011, after eight years of reduction in mortality, life expectancy for both sexes, which amounted to 69.8 years (64 years in men and 75.6 years in women), almost reached the record level of 1986-1989.

At that, the maximum value in women was exceeded in 2009; and the value of the indicator in men has not reached even the maximum of the mid-1960s. However, as we can see, in 2011 we have almost reached the level that is to be achieved by 2015 according to the "Concept for demographic policy up to 2025 ".

The third result is the achieved rate of decline in mortality by causes. In general for 2003-2011 there has been the most significant decrease in mortality rates from external causes (accidents, poisoning, traumas, homicide, suicide): by $40.5 \%$ in men, by $38.9 \%$ in women [14]. It is followed by the reduction of mortality from respiratory diseases, which ranks second. The mortality from this group of causes declined by $27.9 \%$ in men, and by $21.6 \%$ in women. Diseases of the circulatory system occupy the third place in men (reduction by 19.4\%). Mortality from certain infectious and parasitic diseases decreased a bit more significantly in women (by 19.1\%), while the decline in mortality from circulatory diseases was $18.3 \%$. The reduction in mortality from infectious and parasitic diseases in men $(15.6 \%)$ is on the fourth place.

If we look at the period when the government initiatives aimed at reducing mortality have already been put into action, we will see that in 2006-2011 mortality from circulatory diseases ranks second by the rates of decline after the mortality from external causes. And in 2011, when Russia launched regional programs for modernization of health care, the rate of decline in mortality from cardiovascular diseases and external causes are already comparable: $6.3 \%$ and $8.2 \%$, respectively, in men; $6.9 \%$ and $8 \%$ in women.

Fourth, the insufficient growth in life expectancy in the regions with a significant share of deaths from external causes indicates that the reduction in mortality of Russia's population in the 2000s depends to a great extent on the activities related to the modernization of health care. We consider it as a hypothesis in the case of the Republic of Komi. In the 1994-1998 period, when the country was experiencing a decrease in mortality of compensatory type, the life expectancy of the Komi Republic population came very close to that of Russia as a 
whole: the difference reduced from three years to nearly zero. In the 2000s, under a more prolonged period of decline in mortality, the difference between the life expectancy in the Komi Republic and that in Russia in general was still about two years.

\section{Conclusions}

Thus, the federal activities of demographic policy of 2006-2007 extended the positive tendencies in birth rate in the beginning of the 2000s that showed signs of stagnation in 2005-2006. This can be seen in the dynamics of all the fertility indicators. Regional measures slightly improved the birth rate increase in 2012, which reduced significantly in the 2009-2011 period. That is, under the worsening of the age structure of reproductive contingents in Russia, there remains a positive trend in fertility. At the same time, the increase in the total fertility rate results largely from the changes in birth timing. The level of the indicator in 1999 clearly points out the postponement of births by the population throughout the 1990s, which manifested itself rather notably after the 1998 crisis. The level of the total fertility rate in the recent years is determined more and more by the implementation of "postponed" births by older generations and the compression of birth timing of the younger cohorts of population under the influence of federal and regional demographic initiatives.

The negative impact of the age structure of fertile cohorts, which began in 2010-2011, will cause the reduction in the level of fertility in the near future. The structural decrease may be enhanced by the fact that the generations born in the 1980s will have early exhausted their final fertility, and also by the insufficient reproductive activity of the generations born in the 1990s. Russia is to undergo a long period of the birth rate decline, even if the demographic policy is further intensified. Therefore, when developing some new measures of demographic policy, one should focus more on improving the quality structure of fertility, on strengthening the family institution, on the revival and enhancement of spiritual and moral traditions of family relations. We should note that the most efficient measure of the family-oriented demographic policy can be found in considering the second births a priority, because they are the most family-oriented ones. In our opinion, at present, it is necessary to focus the demographic policy on the second births. Especially since these measures will affect the generations born in the 1990s, whose reproductive behavior should be facilitated in order to meet the long-term objectives of Russia's demographic development.

In conclusion, we would like to point out that in 2012 as a result of counter trends in fertility and mortality, the number of births in Russia as a whole almost matched the number of deaths: the ratio of the number of deaths to the number of births amounted to $100.1 \%$, it was $107.3 \%$ in 2011. Life expectancy in Russia has virtually reached 70 years. But this is only half the battle: this figure in Russia was registered a quarter of a century ago, and this is almost 10 years later than in the EL countries. It is necessary to carry out more comprehensive activities connected with health care modernization: the acceleration of Russia's population ageing makes this issue very acute. In addition, Russia still has a very large potential for increasing life expectancy, associated with the population's adverse way of life. And the nature of the problem is not medical but social. The current level of fertility places Russia on the brink of another structural reduction. In these circumstances, the 
priority should be placed on the task of enhancing the reproductive attitudes of small generations born in the $1990 \mathrm{~s}$ and the degree of their implementation, i.e. the task of focusing the demographic policy measures on these generations.

\section{References}

Bodrova, V. (2013). How Many Children Do the Russians Want to Have? Demoscope Weekly, 81-82. Retrieved from http://demoscope.ru/weekly/2002/081/tema01.php

Brief Results of the Sample Survey.(2013). Brief Results of the Sample Survey "Family and Fertility". Retrieved from http://www.gks.ru/free_doc/2010/family.htm

Decree of the President of the Russian Federation. (2013). Decree of the President of the Russian Federation "On the Approval of the Concept for Demographic Policy of the Russian Federation for the Period up to 2025" No. 1351. Retrieved from http://document.kremlin.ru/doc.asp?ID=041941

Demographic Yearbook of the Russian Federation. (1993). Statistical Digest. Moscow.

Federal Law (2006). Federal Law "On Additional Measures of State Support to Families with Children” No. 256-FL of December 29, 2006. The Russian Newspaper.

Federal Law. (1997). Federal Law “On Civil Status Acts”. The Russian Newspaper, 224.

Federal Law. (2006). Federal Law "On the Introduction of Amendments to Certain Legislative Acts of the Russian Federation on the Provision of State Support to the Citizens with Children" No. 207-FL of December 5, 2006. The Russian Newspaper.

Federal Law. (2006). Federal Law "On the Provision of Temporary DisabiUty Allowances, Maternity Allowances to the Citizens Subject to Compulsory Social Insurance” No. 255-FL of December 29, 2006. The Russian Newspaper.

Federal State Statistics Service Website. (nd). Retrieved from http://www.gks.ru/wps/wcm/connect/rosstat_main/rosstat/ru/statistics/population/demograph $\mathrm{y} / \#$

Law of the Republic. (2011). Law of the Republic of Komi "On Additional Measures of Providing Social Support to Families with Children, on the Territory of the Republic of Komi" No. 45 of April 29, 2011. Republic.

Popova L. A., \& Butrim, N. A. (2011). Modem Standards of Reproductive Behavior of the Population and the Objectives of Pro-Family Population Policy. Economic and Social Changes: Facts, Trends, Forecast, 2(14), 73-85.

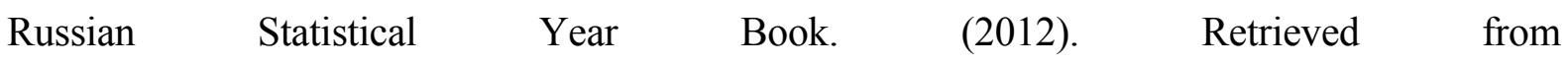
http://www.gks.ru/bgd/regl/bl2_13/Main.htm

Shcherbakova, E. (2012). Demographic Results of 2012 (Part 1). Demoscope Weekly, 541-542, Retrieved from http://demoscope.ru/weekly/2013/0541/barom03.pdf

Zakharov, S. (2012). What the Birth Rate in Russia Will Be. Demoscope Weekly, 495-496. 
Retrieved from http://demoscope.ru/ weekly/2012/0495/tema01.php

\section{Copyright Disclaimer}

Copyright for this article is retained by the author(s), with first publication rights granted to the journal.

This is an open-access article distributed under the terms and conditions of the Creative Commons Attribution license (http://creativecommons.org/licenses/by/3.0/). 